\title{
Nitrogen mineralization in a silandic andosol fertilized with dairy slurry and urea
}

\author{
J. Martínez-Lagos ${ }^{1,2^{*}}$, F. Salazar ${ }^{1}$, M. Alfaro ${ }^{1}$, M. Rosas ${ }^{3}$, and F. Macías ${ }^{2}$ \\ ${ }^{1}$ Instituto de Investigaciones Agropecuarias INIA-Remehue, Osorno, Chile. ${ }^{2}$ Doctorado en Medio Ambiente \\ y Recursos Naturales, Laboratorio de Tecnología Ambiental, Universidad de Santiago de Compostela, 15782 \\ Campus Sur, A Coruña, España. ${ }^{3}$ Universidad Santo Tomás, Osorno, Chile. ${ }^{*}$ Corresponding author: josue. \\ lagos@inia.cl
}

\begin{abstract}
Knowledge about the size and cycle of inorganic $\mathrm{N}$ pool on grasslands is necessary to develop adequate fertilization strategies and to determine the potential pathways of $\mathrm{N}$ losses. The objectives of this study were to: 1) quantify the $\mathrm{N}$ mineralization rates in permanent grassland on an Andosol of southern Chile; and 2) determine the effect of high $\mathrm{N}$ application rates as urea and dairy slurry on this process. Mineralization was measured over a three years period on grassland fertilized with $400 \mathrm{~kg} \mathrm{~N} \mathrm{ha}^{-1} \mathrm{yr}^{-1}$ by acetylene inhibition method, incubating soil cores under field conditions. Subsequently, a laboratory assay was carried out to determine potential residual $\mathrm{N}$ mineralization rate by anaerobic incubation method. Higher $\mathrm{N}$ mineralization was measured on the urea treated plots $\left(314-420 \mathrm{~kg} \mathrm{NH}_{4}^{+}-\mathrm{N} \mathrm{ha}^{-1} \mathrm{yr}^{-1}\right)$ followed by slurry $\left(320-344 \mathrm{~kg} \mathrm{NH}_{4}^{+}-\mathrm{N} \mathrm{ha}^{-1} \mathrm{yr}^{-1}\right)(\mathrm{p}<0.05)$. Most of the N was mineralized during spring and summer seasons $(\mathrm{p}<0.05)$. Laboratory results indicate that slurry treated soil had greater net potential $\mathrm{N}$ mineralization rates than urea $(\mathrm{p}<0.05)$. Results suggest that in Andosols of southern Chile, $\mathrm{N}$ mineralization can be a major $\mathrm{N}$ input into the soil $\mathrm{N}$ budget, with implications for grassland fertilizer managements and pathways of $\mathrm{N}$ loss.
\end{abstract}

Keywords: Nitrogen, mineralization, grassland, slurry, urea, Andosol

\section{Introduction}

Los Lagos and Los Ríos Regions produced $76 \%$ of milk and $34 \%$ of the beef cattle of Chile (ODEPA, 2013a; b). In the past decade, the agriculture production in this area has increased due to agricultural products export and domestic foodstuffs demand (Núñez et al., 2010). This has resulted in greater i) stocking rates, ii) demand for high quality forage and iii) nitrogen (N) fertilizer application rates (Aguilera et al., 2010). Dairy production systems in Los Lagos and Los Ríos Regions are predominantly grazing based, with animals feeding on natural and improved grasslands (Salazar et al., 2014; 2011). Local grasslands evolved 
on volcanic soils, being characterized by high soil organic matter (SOM) concentrations (15-25\%; CIREN, 2005). The $\mathrm{N}$ mineralization is one of the processes that influence the size and cycling of the inorganic-N soil pool (Huygens et al., 2010). This process drives the conversion of passive organic $\mathrm{N}$ forms into inorganic species (Schimel and Bennett, 2004).

Knowing information about the size and the cycling of this inorganic-N pool in this soils is important to develop adequate fertilization strategies and to identify the potential $\mathrm{N}$ loss pathways in livestock systems (Salazar et al., 2011). Studies carried out on this area have demonstrated that most of the applied $\mathrm{N}$ could be lost by gaseous way in form of ammonia $\left(\mathrm{NH}_{3}\right)$ volatilization (e.g. Salazar et al., 2014). Also, some may be lost by nitrous oxide emissions $\left(\mathrm{N}_{2} \mathrm{O}\right)$ (e.g. Vistoso et al., 2012), leaching and/or runoff (e.g. Salazar et al., 2012; 2011). Thus, a good quantitative understanding of the $\mathrm{N}$ cycle in soils is a key factor as for dose and type of $\mathrm{N}$ fertilizer rates to be used under local conditions (Martínez-Lagos et al., 2014).

However, the estimation of $\mathrm{N}$ mineralization rates and available $\mathrm{N}$ supply in southern Chilean volcanic soils is difficult because of the several biotic and abiotic factors affecting this process simultaneously (Lobos et al., 2014). This could be extremely important in southern Chile, where climate conditions are characterized by long rainy seasons and high daily temperature variation periods (e.g. Martínez-Lagos et al., 2014; Salazar et al., 2012). Some of the most important factors influencing the $\mathrm{N}$ mineralization process are the amount of SOM, microbial activity, soil temperature and humidity (Cartes et al., 2009; Ortega and Mardonez, 2005; Videla et al., 2005).

International data on $\mathrm{N}$ mineralization in a range of pasture conditions and grassland soils have been published (e.g. Hatch et al., 2002; 2000; 1991; Antil et al., 2001). In southern Chile the $\mathrm{N}$ mineralization has been determined mainly in forest ecosystems (e.g. Córdova et al., 2012; Rivas et al., 2009; Matus et al., 2008; Huygens et al, 2010), being most of the information generated under laboratory conditions. For the southern Chile area, quantifications of $\mathrm{N}$ mineralization after the application of different sources of organic and mineral fertilizers (e.g. slurries versus urea) under field conditions have not been published.

Given the unique characteristics of the Andosols of southern Chile (Cárdenas et al., 2013) and the simultaneous effect of management and environmental conditions on soil available N (Mora et al., 2007; Pinochet et al., 2000), it is important to evaluate the role of the mineralization process on the available $\mathrm{N}$ input in grassland soils, under field conditions and along the whole year. Thus the objectives of this study were to: 1) quantify the $\mathrm{N}$ mineralization rates in permanent grassland on an Andosol of the Osorno Serie of southern Chile; and 2) determine the effect of high $\mathrm{N}$ application rates from different origin on this process.

\section{Material and Methods}

\subsection{Experimental site}

A field experiment was carried out from March 2008 to February 2011 on a permanent grassland, with no recent history of $\mathrm{N}$ fertilization or livestock grazing (3 years), located at the Instituto de Investigaciones Agropecuarias, INIA-Remehue $\left(40^{\circ} 31^{\prime} \mathrm{S}, 73^{\circ} 03^{\prime} \mathrm{W}\right.$, 65 m.a.s.l). The soil in the area has been classified as an Andosol of the Osorno Serie according to CIREN (2005). In modern systems the soil is ranked as a Silándic Andosol (IUSS, 2007) and typical medium mesic Hapludand (Soil Survey Staff, 2010). This soil has a silty loam texture, being found on gentle rolling hills ( $2-5 \%$ slope), and horizons located in position 
of remnants terraces of the central depression at 90 150m. height (CIREN, 2005; Tosso, 1985).

Previous descriptions reported in national literature indicated that this soil has a $\mathrm{pH} \mathrm{H}_{2} \mathrm{O}$ of 6.12 and 5.91 for depths of $0-16$ and $36-120 \mathrm{~cm}$, respectively, with the predominance of allophon clays and the presence of imogolite, and organo-alifatic and amorphous iron oxides complex; the cation exchange capacity (CEC) is 66.8 to $55.0 \mathrm{cmol}(+) \mathrm{kg}^{-1}$ for depths of 0 -16 and $36-120 \mathrm{~cm}$, respectively (CIREN, 2005; Tosso, 1985). The soil has from a loamy brown to a very dark brown color, depending on the soil depth. This soil also has a moderate permeability and good drainage, with a bulk density between $0.66-0.74$ $\mathrm{g} \mathrm{cm}^{-3}$ (CIREN, 2005). At the experimental site the climate correspond to a typical Mediterranean cold weather, with a 37 year mean annual temperature of $11.3^{\circ} \mathrm{C}\left(5.8\right.$ to $\left.16.8^{\circ} \mathrm{C}\right)$, being July the coldest month with a mean temperature of $7.1{ }^{\circ} \mathrm{C}\left(4.6\right.$ to $\left.9.7^{\circ} \mathrm{C}\right)$ and January the warmest with $15.8^{\circ} \mathrm{C}\left(14.1\right.$ to $\left.17.7^{\circ} \mathrm{C}\right)$. The mean annual precipitation is $1,252 \mathrm{~mm}$. The main specie present at the experimental site was perennial ryegrass (Lolium perenne L.).

At the start of the study and the following years, the experimental site was sprayed with Picloram and Dichrolophenoxiacetic acid (Tordon 24\% SL Dow AgroSciences, and DM 6 67\% SL Dow AgroSciences) in order to eliminate clover and other legumes in the pasture to ensure a null $\mathrm{N}$ contribution through biological $\mathrm{N}$ fixation in the experiment. Prior to the $\mathrm{N}$ treatment application, the plot was plowed employing a cutter bar, leaving a grass standing residue of $5 \mathrm{~cm}$. Initial soil samples (3) at $0-20 \mathrm{~cm}$ were taken to determine the soil texture in the INIA laboratory. Composed samples (3) were also taken after the first $\mathrm{N}$ treatment application, and subsequently each study year until 2011, in order to obtain the chemical soil characterization according to Sadzawka et al. (2006) (Table 1). At the beginning of the experiment, the soil's bulk density (BD) was determined (Sadzawka et al., 2006). At the start of each incubation period, another four additional soil cores per plot were taken in order to provide the baseline of the $\mathrm{N}$ content. This soil samples were immediately analyzed in the laboratory for ammonium $\left(\mathrm{NH}_{4}^{+}\right)$and nitrate $\left(\mathrm{NO}_{3}^{-}\right)$ concentration and dry matter (DM) content.

At the end of the experimental period, $500 \mathrm{~g}$ of soil $(0$ $-10 \mathrm{~cm}$ ) were taken for the determination of potential residual $\mathrm{N}$ mineralization rate (PRNMR) by anaerobic incubation. Beside other $500 \mathrm{~g}$ of soil were taken from different strata $(0-10,10-20,20-30 \mathrm{~cm})$ in the area without $\mathrm{N}$ fertilization. These samples were air dried and analyzed in the Laboratory of Environmental Technology of Santiago de Compostela University, for other soil properties such as carbon (C) content, some micronutrients, and heavy metals.

A target application rate of $400 \mathrm{~kg} \mathrm{~N} \mathrm{ha}^{-1} \mathrm{yr}^{-1}$ was either applied as dairy slurry or as urea $(46 \% \mathrm{~N})$ fertilizer, split in four even applications during the year: March, July, September, and November. This corresponded to one application during fall and winter and two applications during the spring time (Table 2). The experiment was set up in a randomized block design $(n=3)$ with a measuring area of $9 \mathrm{~m}^{2}$. Urea fertilizer was applied by hand and dairy slurry was applied using watering cans fitted with a small splash plate at the end of the spout, which allowed an even distribution. Additionally, a control treatment with no $\mathrm{N}$ addition was included.

Baseline fertilization was applied considering $\mathrm{P}, \mathrm{K}$ and magnesium $(\mathrm{Mg})$ every year. The dairy slurry was obtained directly from the slurry storage at the INIA-Remehue farm before each application date, stored in a slurry tank and sampled for analysis in the laboratory of INIA. Slurry samples were collected 2 weeks prior to application, in order to determine the target application rate in accordance to the different total $\mathrm{N}$ contents of the slurry. During application, 
separate samples of slurry for each replicate $(n=3)$ were collected and chemically analyzed to determine the real applied rate (Table 2).
Rainfall and average soil temperature $(5 \mathrm{~cm})$ was registered during the experimental period in INIARemehue meteorological station located less than $3 \mathrm{~km}$ from the experimental site (Figure 1).

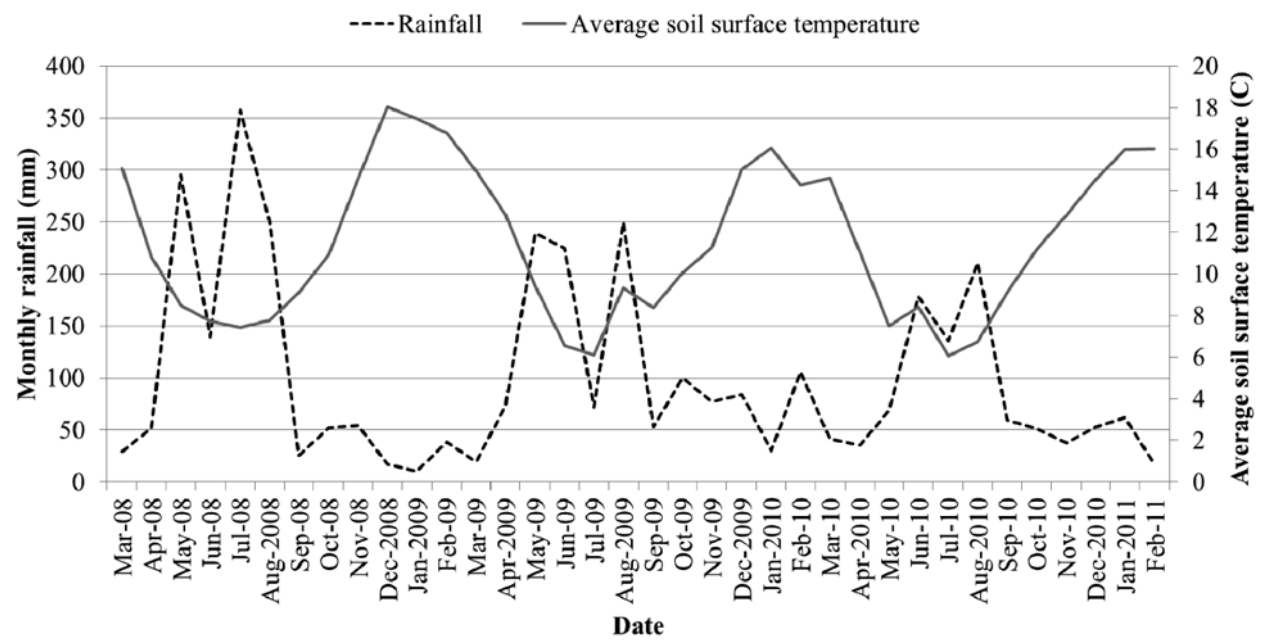

Figure 1. Seasonal pattern of monthly rainfall $(\mathrm{mm})$ and average soil temperature $\left({ }^{\circ} \mathrm{C}\right)$ for the experimental period.

Table 1. Chemical soil characterization $( \pm$ SEM) of the plots at the experimental site $(n=3)$.

\begin{tabular}{|c|c|c|c|c|c|c|c|c|c|c|c|c|c|c|}
\hline \multirow{2}{*}{ Year } & \multirow{2}{*}{ Treatment } & $\mathbf{P}$ & $\mathbf{N}$ & $\mathrm{pH}$ & $\mathrm{pH}$ & OM & $\mathrm{Ca}$ & Mg & K & $\mathrm{Na}$ & Al int & S. Bases & AL sat. & $\mathbf{S}$ \\
\hline & & $\mathrm{ppm}$ & Ppm & $\mathrm{H}_{2} \mathrm{O}$ & $\mathrm{CaCl}_{2}$ & $\%$ & \multicolumn{6}{|c|}{$\mathrm{cmol}(+) / \mathrm{kg}$} & $\%$ & ppm \\
\hline \multirow[t]{2}{*}{2008} & ${ }^{n}$ & $40.2 \pm 1.30$ & $85.5 \pm 24.65$ & $5.9 \pm 0.10$ & $5.4 \pm 0.03$ & $19.9 \pm 0.69$ & $11.7 \pm 0.14$ & $2.6 \pm 0.21$ & $1.2 \pm 0.2$ & $0.4 \pm 0.18$ & $0.0 \pm 0.00$ & $15.9 \pm 0.47$ & $0.3 \pm 0.03$ & $12.3 \pm 2.94$ \\
\hline & Control & $51.8 \pm 10.40$ & $61.3 \pm 11.79$ & $6.0 \pm 0.07$ & $5.4 \pm 0.07$ & $21.7 \pm 1.04$ & $12.0 \pm 0.54$ & $2.6 \pm 0.56$ & $0.6 \pm 0.02$ & $0.2 \pm 0.01$ & $0 . I \pm 0.01$ & $15.4 \pm 0.88$ & $0.4 \pm 0.08$ & $10.4 \pm 3.23$ \\
\hline \multirow[t]{3}{*}{2009} & Urea & $36.8 \pm 6.68$ & $115.1 \pm 12.25$ & $5.7 \pm 0.03$ & $5.2 \pm 0.04$ & $23.0 \pm 1.11$ & $10.0 \pm 0.75$ & $1.6 \pm 0.11$ & $0.5 \pm 0.06$ & $0.2 \pm 0.03$ & $0.1 \pm 0.01$ & $12.2 \pm 0.96$ & $0.8 \pm 0.10$ & $13,8 \pm 1.96$ \\
\hline & Slurry & $65.4 \pm 7.86$ & $79.7 \pm 13.82$ & $6.0 \pm 0.06$ & $5.5 \pm 0.05$ & $25.6 \pm 2.19$ & $11.5 \pm 0.49$ & $3.6 \pm 0.15$ & $0.9 \pm 0.16$ & $0.4 \pm 0.02$ & $0.1 \neq 0.01$ & $16.3 \pm 0.31$ & $0.4 \pm 0.04$ & $23.6 \pm 1.80$ \\
\hline & Control & $45.4 \pm 6.30$ & $26.3 \pm 4.25$ & $6.0 \pm 0.04$ & $5.3 \pm 0.04$ & $21.1 \pm 0.84$ & $11.4 \pm 0.37$ & $1.9 \pm 0.28$ & $0.5 \pm 0.07$ & $0.1 \pm 0.01$ & $0.1 \pm 0.01$ & $15.1 \pm 0,08$ & $0.7 \pm 0.65$ & $13.8 \pm 1.59$ \\
\hline \multirow[t]{3}{*}{2010} & Urea & $42.4 \pm 5.94$ & $93.6 \pm 3.46$ & $5.8 \pm 0.09$ & $5.1 \pm 0.09$ & $20.3 \pm 0.63$ & $9.6 \pm 0.48$ & $1.2 \pm 0.14$ & $0.2 \pm 0.01$ & $0.1 \pm 0.00$ & $0.2 \pm 0.03$ & $11.0 \pm 0.57$ & $1.5 \pm 0.39$ & $13.7 \pm 0.63$ \\
\hline & Slurry & $54.7 \pm 3.43$ & $60.6 \pm 3.98$ & $6.0 \pm 0.00$ & $5.3 \pm 0.02$ & $24.6 \pm 1.88$ & $11.8 \pm 0.43$ & $2.3 \pm 0.17$ & $0.5 \pm 0.13$ & $0.2 \pm 0.02$ & $0.1 \pm 0.00$ & $14.9 \pm 1.24$ & $0.7 \pm 0.04$ & $11.3 \pm 0.47$ \\
\hline & Control & $37.3 \pm 1.83$ & $31.5+2.54$ & $6.0 \pm 0.09$ & $5.3 \pm 0.10$ & $21.1 \pm 1.05$ & $10.9 \pm 0.76$ & $2.3 \pm 0.03$ & $0.6 \pm 0.17$ & $0.2+0.01$ & $0.1 \pm 0.01$ & $14.1 \pm 0.94$ & $0.4 \pm 0.10$ & $12.6 \pm 3.17$ \\
\hline \multirow[t]{2}{*}{2011} & Urea & $33.8 \pm 3.39$ & $72.1 \pm 25.86$ & $5.6 \pm 0.14$ & $5.0 \pm 0.06$ & $20.2 \pm 0.94$ & $8.8 \pm 0.71$ & $1.5 \pm 0.20$ & $0.2 \pm 0.01$ & $0.1 \pm 0.02$ & $0.1 \pm 0.03$ & $10.6 \pm 0.69$ & $1.1 \pm 0.27$ & $13.7 \pm 2.78$ \\
\hline & Slurry & $49.9 \pm 9.21$ & $41.4 \pm 3.39$ & $6.0 \pm 0.03$ & $5.3 \pm 0,02$ & $21.3 \pm 0.73$ & $10.9 \pm 0.39$ & $3.4 \pm 0.37$ & $1.0 \pm 0.11$ & $0.3 \pm 0.00$ & $0.1 \pm 0.00$ & $15.5 \pm 0.22$ & $0.3 \pm 0.03$ & $22.1 \pm 2.08$ \\
\hline
\end{tabular}

${ }^{*}$ Results of the soil prior to $\mathrm{N}$ treatment addition. 
Table 2. Application date, characterization of dairy slurry and total rate of the $\mathrm{N}$ fertilizers applied during the study years.

\begin{tabular}{|c|c|c|c|c|c|c|c|c|}
\hline \multirow{3}{*}{ Year } & \multirow{3}{*}{ Date of application } & \multicolumn{6}{|c|}{ Dairy slurry } & \multirow{3}{*}{$\begin{array}{c}\begin{array}{c}\text { Urea } \\
\text { fertilizer }\end{array} \\
(\mathrm{kg} \mathrm{N})\end{array}$} \\
\hline & & Dry matter & N Kjeldahl & $\mathrm{NH}_{4}{ }^{+}-\mathrm{N}$ & Application rate & $\mathrm{N}$ applied & $\mathrm{N}$ applied & \\
\hline & & $(\%)^{2}$ & $\left(\mathrm{~kg} \mathrm{t}^{-1}\right)^{2}$ & $\left(\mathrm{~kg} \mathrm{t}^{-1}\right)^{2}$ & $\left(m^{3} h a^{-1}\right)$ & $(\mathrm{kg} \mathrm{N})$ & $\left(\mathrm{kg} \mathrm{NH}_{4}^{+}-\mathrm{N}\right)$ & \\
\hline \multirow{6}{*}{2008} & March $31^{\text {th }}$ & 4.6 & 1.5 & 0.5 & 80 & 117 & 41 & 100 \\
\hline & July $25^{\text {th }}$ & 4.8 & 1.4 & 0.4 & 80 & 108 & 33 & 100 \\
\hline & September $29^{\text {th }}$ & 4.1 & 1.6 & 0.6 & 60 & 94 & 36 & 100 \\
\hline & November $27^{\text {th }}$ & 4.1 & 1.8 & 0.7 & 60 & 108 & 42 & 100 \\
\hline & Average & 4.4 & 1.5 & 0.6 & 70 & 107 & 38 & 100 \\
\hline & Total & & & & & 427 & 152 & 100 \\
\hline \multirow{6}{*}{2009} & March $26^{\text {th }}$ & 4.7 & 1.8 & 0.7 & 70 & 127 & 47 & 100 \\
\hline & July $27^{\text {th }}$ & 4.8 & 1.9 & 0.7 & 50 & 93 & 34 & 100 \\
\hline & September $28^{\text {th }}$ & 5.2 & 1.2 & 0.3 & 90 & 110 & 23 & 100 \\
\hline & December $07^{\text {th }}$ & 1.7 & 1.3 & 0.4 & 65 & 47 & 24 & 100 \\
\hline & Average & 4.9 & 1.6 & 0.5 & 69 & 94 & 32 & 100 \\
\hline & Total & & & & & 377 & 128 & 100 \\
\hline \multirow{6}{*}{2010} & March $31^{\text {th }}$ & 2.2 & 0.8 & 0.3 & 95 & 104 & 30 & 100 \\
\hline & July $29^{\text {th }}$ & 1.8 & 0.6 & 0.2 & 120 & 98 & 18 & 100 \\
\hline & September $22^{\text {th }}$ & 3.3 & 1.0 & 0.2 & 130 & 117 & 20 & 100 \\
\hline & December $10^{\text {th }}$ & 3.2 & 1.4 & 0.4 & 90 & 130 & 28 & 100 \\
\hline & Average & 2.6 & 0.9 & 0.3 & 109 & 112 & 24 & 100 \\
\hline & Total & & & & & 449 & 96 & 100 \\
\hline
\end{tabular}

* Presented data for each application date represent the mean of the 3 replicate samples.

\subsection{Field $N$ mineralization by acetylene jar incubation}

The field $\mathrm{N}$ mineralization was measured by the soil core aerobic incubation technique with acetylene $\left(\mathrm{C}_{2} \mathrm{H}_{2}\right)$ inhibition (Hatch et al., 1990; 1991; Jarvis et al., 2001) from March 2008 - February 2009 (first year), March 2009 - February 2010 (second year), and March 2010 - February 2011 (third year). Briefly, four cylindrical soil cores $(2.6 \mathrm{~cm}$ diameter $\mathrm{x} 10 \mathrm{~cm}$ deep) were taken randomly from each plot employing a steel corer. These cores were placed in a glass jar $(1000 \mathrm{~mL})$ maintaining the soil structure. The jars were sealed with a metal lid, which has a rubber septum fixed in the center. Each jar was labeled and buried in the soil, exposing only the upper surface of the lid, which allows incubating the samples at soil temperature.

Using a hypodermic syringe, $20 \mathrm{~mL}$ of air was withdrawn from the headspace of each jar. This air was discarded and later $20 \mathrm{~mL}$ of $\mathrm{C}_{2} \mathrm{H}_{2}$ was injected providing a $2 \% \mathrm{v} / \mathrm{v}$ concentration. For the purpose of this research, a 14 day incubation period was carried out during each month of the three evaluation years (this period comprised the first 14 days of each month).
At each sampling time, the fresh and the incubated soil were taken to the laboratory, where $\mathrm{NH}_{4}^{+}$and $\mathrm{NO}_{3}$ concentrations and DM content were determined. Nitrate values were not taken into consideration in the current study according to Hatch et al. $(1990 ; 1991)$. Ammonium was determinate by a $2 \mathrm{M}$ Potassium Chloride $(\mathrm{KCl})$ extraction. The mix was shaken for $1 \mathrm{~h}$ at $180 \mathrm{rpm}$, and the suspension was filtered using a Whatmann $\mathrm{N}^{\circ} 1$ filter paper. Soil extracts were kept at $<4^{\circ} \mathrm{C}$ until analysis by automated colorimetry (SKALAR, SA 4000, Breda, The Netherlands). Dry matter content was also determined by drying a fresh soil sample $(50 \mathrm{~g})$ at $105^{\circ} \mathrm{C}$ for $24 \mathrm{~h}$, in agreement with to Sadsawka et al. (2006).

Mineralization for any incubation period was calculated from the difference between the $\mathrm{N}^{-} \mathrm{NH}_{4}^{+}$ concentration in the soil at the start and the end of the incubation time $\left(\mathrm{mg} \mathrm{NH}_{4}^{+}-\mathrm{N} \mathrm{kg}\right.$ dry soil), because all $\mathrm{NH}_{4}^{+}$was the only product in the incubated soil with the acetylene. Negative rates of $\mathrm{N}$ mineralization were assumed as net immobilization or assimilation periods according to Hatch et al. (1998). The daily mineralization rate $\left(\mathrm{kg} \mathrm{NH}_{4}^{+}-\mathrm{Nha}^{-1} \mathrm{~d}^{-1}\right)$ was obtained by dividing the amount of mineralized $\mathrm{N}$ in an incubation 
period by the number of days under incubation. The total mineralization per year $\left(\mathrm{kg} \mathrm{NH}_{4}^{+}-\mathrm{N} \mathrm{ha}^{-1} \mathrm{yr}^{-1}\right)$ was estimated as the cumulative amount of positive mineralization values within periods. Because field incubations were carried out just for the first 14 days of each month, the total $\mathrm{N}$ mineralization per month was arithmetically interpolated taking into account the values of the incubation period per day and the number of days without an incubation process. At the end, the whole $\mathrm{N}$ mineralization per month was calculated by the addition of the results of the incubated period plus the proportional amount of $\mathrm{N}$ mineralized according to the previously described interpolation.

\subsection{Potential residual $N$ mineralization rate by anaerobic incubation}

At the end of the field experimental period, soil samples were randomly taken from the plots, where $500 \mathrm{~g}$ of soil $(0-10 \mathrm{~cm})$ was extracted from each plot. This soil was air dried, sieved $(2.0 \mathrm{~mm})$ and analyzed for PRNMR. A modification of the potential anaerobic incubation mineralization method of Lober and Reeder (1993) was employed to determine the $\mathrm{N}$ release. Briefly, $5 \mathrm{~g}$ of dry soil was weighed into polypropylene $50 \mathrm{~mL}$ syringes and $13 \mathrm{~mL}$ of distilled water was added. Tubes were sealed after air extraction, secured into a metal rack and kept at $40{ }^{\circ} \mathrm{C}$ for 7 days. At the end of the incubation period, $37 \mathrm{~mL}$ of $2.7 \mathrm{M} \mathrm{KCl}$ was injected and shaken for $1 \mathrm{~h}$ at 180 $\mathrm{rpm}$. The suspension was filtered (Paper Whatmann $\mathrm{N}^{\circ}$ 1) and the content of $\mathrm{NH}_{4}^{+}$in the extracts was determined with an automatic analyzer (SKALAR, SA 4000, Breda, The Netherlands).

Available soil $\mathrm{NH}_{4}^{+}-\mathrm{N}$ was also determined before incubation in order to register the initial mineral $\mathrm{N}$ at time zero (day 0 ). The potential $\mathrm{N}$ mineralization was calculated based on the difference in $\mathrm{NH}_{4}^{+}$ concentration pre-and post-incubation period. Net potential residual $\mathrm{N}$ mineralization was obtained by subtracting the total mineralization of $\mathrm{N}$ fertilized plots minus control plots.

\subsection{Statistical analysis}

ANOVA was used to statically analyze the $\mathrm{N}$ mineralization parameters from both, field and laboratory determinations (Genstat 7.1). Tuckey test was used to determine significant differences among treatments at a $95 \%$ confidence level.

\section{Results and Discussion}

\subsection{Climate and soil's physical and chemical properties}

Average annual cumulative rainfall in the experimental site during the study period (March 2008 - February 2011) was $1,201 \mathrm{~mm}$, being almost equal to the 37 year average which is $1,252 \mathrm{~mm}$. The mean annual cumulative rainfall was distributed as follows: $1,322 \mathrm{~mm}, 1,328 \mathrm{~mm}$ and $951 \mathrm{~mm}$ for years one, two and three, respectively, being June August the months with higher rainfall, and January - March those with the least amount of rainfall water (Figure 1). The average annual soil temperature was similar during the whole study period $\left(11^{\circ} \mathrm{C}\right)$, with the minimum temperature during winter (July - September), with an average of $4{ }^{\circ} \mathrm{C}$ for the three evaluation years. The maximum temperature was registered in summertime (December to January) with an average of $19{ }^{\circ} \mathrm{C}$ (Figure 1). The trend of rainfall and temperature values followed the historical pattern registered by the INIA-Remehue meteorological station.

Results indicate the soil has suitable physicalchemical properties for grassland production having a loam texture $(36.6 \pm 6.72 \%$ of sand, $46.5 \pm 3.20 \%$ of 
silt and $16.8 \pm 3.67 \%$ of clay at $0-20 \mathrm{~cm}$.), moderate acidity $(<6.0)$, and regular levels of total $\mathrm{N}, \mathrm{Ca}, \mathrm{Mg}$, $\mathrm{K}, \mathrm{Na}$, and $\mathrm{Al}$ int. The soil is well supplied with $\mathrm{P}$ (total and assimilable) in the surface. Beside there was a low Al saturation, high amount of exchangeable bases and very high OM content (Table 1). Results of the samples sent to the Laboratory of Environmental Technology of Santiago de Compostela University indicated a $\mathrm{pH}(\mathrm{KCl})$ of 4.7, 4.0, 3.9 for $0-10,10$ $-20,20-30 \mathrm{~cm}$ soil strata, respectively. These $\mathrm{pH}$ values are lower than those determined by INIA for the experimental plots, which could be attributed to the natural heterogeneity or induced by the $\mathrm{N}$ treatments.

The total $\mathrm{C}$ were $9.8 \%, 5.2 \%$, and $3.2 \%$ for $0-10$, $10-20,20-30 \mathrm{~cm}$ soil strata, respectively while the organic one was $9.6 \%, 5.0 \%$, and $3.0 \%$ for $0-10$, $10-20,20-30 \mathrm{~cm}$ soil strata, respectively. Phosphate $\left(\mathrm{PO}_{4}{ }^{3-}\right)$ retention was $90.1 \%, 95.1 \%$, and $95.2 \%$ for 0 $-10,10-20,20-30 \mathrm{~cm}$ soil strata, respectively. The reported CIC was high, depending almost entirely of the high OM content. Reported results showed regular levels of micronutrients $(\mathrm{S}, \mathrm{Fe}, \mathrm{Si}, \mathrm{Mn})$ and also of the heavy metals (As, $\mathrm{Cd}, \mathrm{Co}, \mathrm{Cr}, \mathrm{Cu}, \mathrm{Ni}, \mathrm{Pb}$, and $\mathrm{Zn}$ ). Macro and micronutrients are in accordance to Vistoso et al. (2009) who described some of the chemical characteristics of Osorno Serie and three types of southern Chilean Andosols.

The melanic index was nearby 1.5 for all soil strata, and the andic index was 3.2,2.9, and 2.7 for $0-10,10$ $-20,20-30 \mathrm{~cm}$ soil strata, respectively. This melanic index is characteristic of melanic Andosols, whence these analyzed soils could be closer to aluandic Andosols.

\subsection{Dairy slurry and urea fertilizer application}

Dairy slurry used in this study was typical of that produced in dairy units of southern Chile, with low
DM and nutrients concentration due to the high contribution of clean and dirty water into the slurry pond. The average values for the three years were: $3.9 \pm 0.7 \%$ of DM, $1.3 \pm 0.2 \mathrm{~kg} \mathrm{~N}$ Kjeldahl $\mathrm{t}^{-1}$ and $0.5 \pm 0.1 \mathrm{~kg} \mathrm{~N}-\mathrm{NH}_{4}^{+} \mathrm{t}^{-1}$ (fresh weight basis) (Table 2).

Despite the normal variability within the year, slurry application rates were very close to the target rate (three years average of $418 \pm 21 \mathrm{~kg} \mathrm{~N} \mathrm{ha}^{-1} \mathrm{yr}^{-1}$; Table 2). The difference observed between the target and the actual rate could be due to small variations in the $\mathrm{N}$ concentrations at the sampling and application days (2 weeks difference).

\subsection{Field $N$ mineralization}

Control plots with no $\mathrm{N}$ fertilization showed a three year average mineralization of $193 \pm 3.5 \mathrm{~kg} \mathrm{NH}_{4}{ }^{+} \mathrm{N}$ $\mathrm{ha}^{-1}$, with a daily average mineralization rate of $0.52 \pm 0.247 \mathrm{~kg} \mathrm{NH}_{4}^{+}-\mathrm{N} \mathrm{ha}^{-1}(p>0.05$ between years and $p<0.05$ between treatments; Figure 3). These results are in accordance with Lobos et al. (2014) who registered a similar $\mathrm{N}$ mineralization in control plots in the same soil type and using the same field methodology.

In the slurry treated plots the three year average mineralization was $336 \pm 5.9 \mathrm{~kg} \mathrm{NH}_{4}^{+}-\mathrm{N} \mathrm{ha}^{-1}$, with a daily mineralization rate of $0.92 \pm 0.454 \mathrm{~kg} \mathrm{NH}_{4}^{+}-\mathrm{N}$ ha $^{-1}$ day $^{-1}$ ( $p>0.05$ between years and $p<0.05$ between treatments; Figure 3). Meanwhile, in urea treated plots the mineralized $\mathrm{N}$ averaged $382 \pm 5.1 \mathrm{~kg} \mathrm{NH}_{4}^{+}$$\mathrm{N} \mathrm{ha}^{-1}$ and the daily rate was $1.06 \pm 0.373 \mathrm{~kg} \mathrm{NH}_{4}^{+}-\mathrm{N}$ ha $^{-1}$ day $^{-1}$ ( $p>0.05$ between years and $\mathrm{p}<0.05$ between treatments; Figure 3).

The statistical differences between treatments during the evaluation years indicate an effect of the addition of fertilizers in soil $\mathbf{N}$ mineralization. The average net $\mathrm{N}$ mineralization (subtracting the control value) of the three-year study period accounted $143 \pm 2.4$ and $189 \pm 1.6$ $\mathrm{kg} \mathrm{NH}_{4}^{+}-\mathrm{N} \mathrm{ha}^{-1}$ for slurry and urea, respectively 
$(p>0.05)$, with an average net $\mathrm{N}$ mineralization rate of $0.4 \pm 0.21$ and $0.5 \pm 0.13 \mathrm{~kg} \mathrm{NH}_{4}^{+}-\mathrm{N} \mathrm{ha}^{-1}$ day $^{-1}$ for slurry and urea, respectively $(p>0.05)$.

Seasonal $\mathrm{N}$ mineralization variability in the experimental period was registered. When slurry was applied $9 \%, 17 \%, 41 \%$, and $34 \%$ of the $\mathrm{N}$ mineralization took place during autumn, winter, spring, and summer, respectively $(p<0.05)$; meanwhile, $9 \%, 20 \%, 35 \%$, and $36 \%$ took place during autumn, winter, spring, and summer, respectively, when urea was applied. The results indicate that on average $75 \%$ and $71 \%$ of the $\mathrm{N}$ was mineralized during the spring-summer period for slurry and urea treatments, respectively, with statistically differences $(\mathrm{p}<0.05)$ in comparison to the $\mathrm{N}$ mineralization registered in the autumn-winter period.

\subsection{Results of potential residual $N$ mineralization rate by anaerobic incubation}

No significant differences between treatments were found for total PRNMR ( $p>0.05)$. However, the net PRNMR was considerably higher when applying slurry than urea $(436 \pm 20.1$ and $126 \pm 102.9 \mathrm{mg}$ $\mathrm{NH}_{4}^{+}-\mathrm{N} \mathrm{kg}^{-1}$ dry soil for slurry and urea, respectively) $(p<0.05)$. The soil of urea treated plots only reached a quarter of the total amount of mineralized $\mathrm{N}$ when slurry was employed as N source (Figure 2).

The PRNMR per day of incubation period could be estimated in $134 \pm 0.8,196 \pm 3.1$ and $152 \pm 15.4 \mathrm{mg}$ $\mathrm{NH}_{4}^{+}-\mathrm{N}$ ha ${ }^{-1}$ dry soil for control, slurry and urea, respectively $(\mathrm{p}<0.05)$. These results are in accordance to Alfaro et al. (2009b).

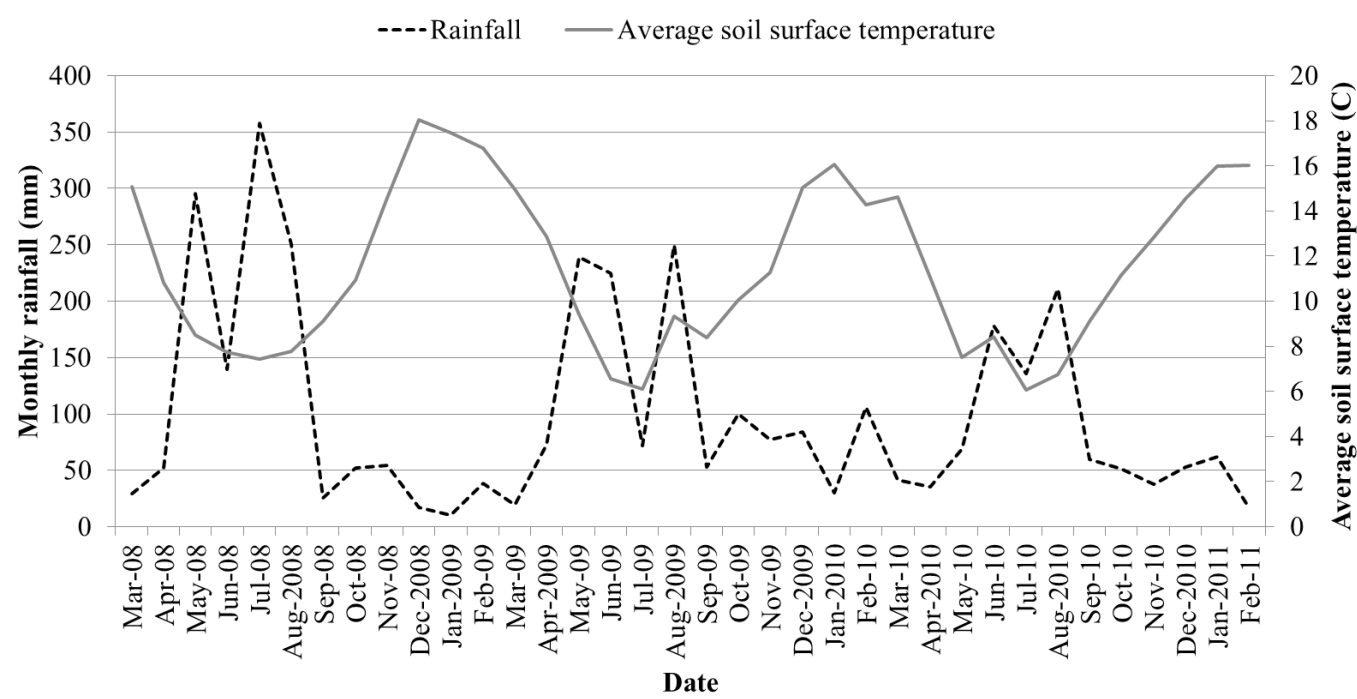

Figure 2. Results of total potential residual $\mathrm{N}$ mineralization rate $(\mathrm{PRNMR})( \pm \mathrm{SEM})$ and daily rate per treatment $(n=3)$. 


\subsection{Discussion}

Through the study years, there has been an apparent net release of inorganic $\mathrm{N}$, being mineralization and fertilization major $\mathrm{N}$ inputs in local grasslands (Salazar et al., 2012; Mora et al., 2007). The soils in the study area are often very high in OM, hence there is a large potential of inorganic $\mathrm{N}$ supply released by the mineralization (Cárdenas et al., 2013). This could represent an important potential environmental risk to groundwater bodies due to $\mathrm{N}$ losses via $\mathrm{NO}_{3}{ }^{-}$ leaching. These losses could be influenced by the high pluviometry of the area and the good water infiltration capacity this type of soil (Salazar et al., 2012).

However, this has not been reported in studies conducted in this type of soil, in which leached $\mathrm{NO}_{3}^{-}$was low, with no significant $\mathrm{N}$ losses despite a high amount of applied N (e.g. Salazar et al., 2012; 2011). Regarding this point, Cárdenas et al. (2013) mentioned that the combination of $\mathrm{NH}_{4}^{+}-\mathrm{N}$ retention together with delayed nitrification processes account for the low leaching rates in Andosol soils of southern Chile.

In the current study, the $\mathrm{N}$ input increased soil $\mathrm{N}$ mineralization $(p<0.05$; Table 3$)$. This effect is reflected in the mean daily $\mathrm{N}$ mineralization rate, which fluctuated in response to the added $\mathrm{N}$ and the influence of climate variables according the season (Figure 3). Results indicate that in fertilized plots the $\mathrm{N}$ mineralization rates were more variable than in control plots with no $\mathrm{N}$ addition, probably due to the effect of the $\mathrm{N}$ fertilizer on the activation of soil microbial communities.

Mineralization rates generally peaked at the end of winter, staying almost constant during the spring and slightly reducing during summer. The rates kept decreasing from the beginning of fall and became significantly reduced during the winter seasons (Figure 3). Immobilization periods were observed in all the treatments throughout fall and winter seasons, showing a clear and measurable temporal pattern. Despite the $\mathrm{N}$ fertilization carried out in late March of each year (Table 2), negative rates were frequently found during June - July, April - June, and May July for years one, two and three, respectively. Within treatments, control plots registered the highest period of negative rates during the first year, while slurry during the second and third study years. This could be explained by one of the major variables determining $\mathrm{N}$ mineralization which is the soil water content and its relation with the SOM (Videla et al., 2005). The decrease in mineralization rates during these months could have been a response of the biological activity to the restricted aeration environment and to the decrease in the soil temperature, which is in agreement with the results of Ortega and Mardónez (2005).

In Andosols the initial phase of $\mathrm{N}$ immobilization may last approximately 10 days under favorable temperature conditions $\left(20{ }^{\circ} \mathrm{C}\right)$ or even 30 days as temperature decreases (Aguilera et al., 2010). During immobilization periods the microorganisms convert the inorganic $\mathrm{N}$ into organic and some organic $\mathrm{N}$ fixation could happen in the soil $\mathrm{OM}$ and minerals (Hatch et al., 2002; 1998). If the $\mathrm{N}$ is acquired by the cells of microbial organisms, only when it's decomposed or mineralized it can be used by the grassland plants (Hatch et al., 2002; 2000). In fall season a decrease in $\mathrm{N}$ mineralization rates was observed, probably associated to consumption processes such as plant uptake, leaching or gaseous emissions (Hatch et al., 2000; 1998).

In the Andosol of Osorno Serie in southern Chilean grasslands, the $\mathrm{N}$ uptake by plant roots (e.g. Alfaro et al., 2013) and the $\mathrm{NH}_{3}$ volatilization processes (e.g. Salazar et al., 2014; Martínez-Lagos et al., 2014; Núñez et al., 2010) could be major N outputs. Dry matter production and $\mathrm{N}$ uptakes in local grasslands 
could be high as had been demonstrated by Salazar et al. (2012) who registered grassland yields up to 18,428 and 17,604 $\mathrm{kg} \mathrm{DM} \mathrm{ha}^{-1} \mathrm{yr}^{-1}$ and $\mathrm{N}$ uptakes up to 505 and $369 \mathrm{~kg} \mathrm{ha}^{-1} \mathrm{yr}^{-1}$ in the same type of soil and area, when the same dose of urea and slurry were applied as $\mathrm{N}$ source, respectively.

Alfaro et al. (2013) in a lysimeter experiment using the same soil type found a low real $\mathrm{N}$ use efficiency (NUE) associated with the $\mathrm{N}$ adsorption processes in the labile fractions of SOM, the increase in microbial biomass and the physical-chemical adsorption of $\mathrm{NH}_{4}^{+}-\mathrm{N}$ in soil clays. These processes could be related with the continuous variations in the $\mathrm{N}$ mineralization rates during some seasons in the current study. Beside it is necessary to consider that Andosol soils of Osorno Serie could require a higher amount of total $\mathrm{N}$ in order to produce the same amount of available $\mathrm{N}$, in comparison with other volcanic soils (Cárdenas et al., 2013).

Regarding the influence of the associated mineralization processes in the occurrence of $\mathrm{N}$ gaseous losses (e.g. $\mathrm{NH}_{3}$ and $\mathrm{N}_{2} \mathrm{O}$ ), it's important to consider that most of the $\mathrm{NH}_{4}^{+}-\mathrm{N}$ could remain in the top $10 \mathrm{~cm}$ of soil, and most of the $\mathrm{NH}_{3}$ emission is mainly performed at the soil surface (Martínez-Lagos et al., 2014). In the $\mathrm{N}_{2} \mathrm{O}$ emission case, a decrease of soil $\mathrm{OM}$ and an increase in $\mathrm{pH}$ in depth, such as those happen in the $10-30 \mathrm{~cm}$ stratum, could affect the microorganisms that work in the mineralization process due to the lack of oxygen. This anoxic condition enhances $\mathrm{N}_{2} \mathrm{O}$ exchange according to Vistoso et al. (2012).

The flooded soil conditions resulting of the large amount of rain events during the winter season in southern Chile could also favor the appearance of these emissions (Figure 3). However, preliminary results of studies carried out on local Andosols of Osorno Serie showed that $\mathrm{N}$ loss due $\mathrm{N}_{2} \mathrm{O}$ emissions is very low (Vistoso et al., 2012). In contrast, Salazar et al.
(2014), Martínez-Lagos et al. (2014) and Salazar et al. (2012) reported high $\mathrm{N}$ losses due $\mathrm{NH}_{3}$ volatilization in local Andosols of Osorno Serie, which implied that $\mathrm{NH}_{3}$ emissions could be the key aspect to improve $\mathrm{N}$ use efficiency in southern Chilean grasslands, and that $\mathrm{N}$ input by fertilization must take into consideration the $\mathrm{N}$ supplied by the soil mineralization in order to reduce $\mathrm{N}$ losses by this pathway.

Regarding the influence of the $\mathrm{N}$ source, results indicate that soil responds in various ways to the $\mathrm{N}$ input. When slurry is applied it's easily degradable substances, such as various forms of available $\mathrm{C}$, amino-sugars, proteins, hemicellulose, cellulose and a large quantity of exogenous microorganisms (Aguilera et al., 2010; Salazar et al., 2007), could have increased rapidly the activity of some bacteria and protozoa organism (Hatch et al., 2002; 2000). According to Aguilera et al. (2010) after dairy slurry applications the soil $\mathrm{pH}$ could change, this may encourage the potential of $\mathrm{NH}_{3}$ volatilization which is not favored by acid soil conditions (Martínez-Lagos et al., 2014). However these losses might not be as high as in the case of urea fertilizer, because only a part of the slurry is complete infiltrated into the soil (Salazar et al., 2014). The slurry that effectively infiltrates in the soil represents a supply of labile SOM, which C:N ratios quickly enable the activity of microorganisms (Hatch et al., 2002).

The activity of the soil microbial biomass is also determined by the quantity and quality of SOM (Rivas et al., 2009; Antil et al., 2001; Pinochet et al., 2000). When the slurry is applied, microbes could produce a fast immobilization of the slurry $\mathrm{N}$, following by some periods of net mineralization after the $\mathrm{N}$ demands of the growing biomass pool were satisfied (Aguilera $e t$ al., 2010; Salazar et al., 2007). The subsequent $C$ and $\mathrm{N}$ limitation could prevent a long-term maintenance of the enhanced biomass pool, which could result in temporary elevations of $\mathrm{N}$ mineralization rates when 
this biomass is decomposed (Rivas et al., 2009; Matus et al., 2008).

Aguilera et al. (2010) reported an efficient metabolic activity of the soil microbial biomass under dairy farms located in southern Chilean Andosols. However, despite the large $\mathrm{N}$ inputs in the current study (Table 2), a clear pattern showing a short-term increasing tendency of mineralization rates following the application of slurry as $\mathrm{N}$ source or the longterm tendency following the application of mineral $\mathrm{N}$ fertilizers was not always observed after the $\mathrm{N}$ applications (Figure 3). This can be explained by a rapid biological immobilization by soil microbiota or by a rapid abiotic immobilization according to Cárdenas et al. (2013), Huygens et al. (2010) and Antil et al. (2001) statements.

When urea is added to soils with high OM content, the microbial biomass is also stimulated showing a positive response in the $\mathrm{N}$ mineralization rates. The response of the soil to the urea fertilizer addition largely depends on its own characteristics (Hatch et al., 2000). One example is that colloidal materials or organic complex and amorphous clay minerals which could favor the adsorption of some nutrients by the establishment of sites to the microbial populations, which can be reflected in higher $\mathrm{N}$ mineralization rates (Cárdenas et al., 2013; Matus et al., 2008).

Martínez-Lagos et al. (2014) indicated that some of the soil and climate conditions can influence the amount of $\mathrm{NH}_{4}^{+}-\mathrm{N}$ in soil and therefore the magnitude of gaseous losses (e.g. $\mathrm{NH}_{3}$ emissions) after urea fertilization. These conditions include soil $\mathrm{pH}$, high air and soil temperatures, frequent and intense rain episodes, and strong and sustained wind velocity.

The results of the current field experiment were higher than the mineralization rates reported by Alfaro et al. (2009a) with the same incubation technique, using Andosols of the same area. The difference can be attributed to the high urea fertilizer and dairy slurry dose applied to the soil in the current trial $(400 \mathrm{~kg}$ $\mathrm{N}$ ha $\left.\mathrm{yr}^{-1}\right)$ in comparison with the low dose $(68 \mathrm{~kg} \mathrm{~N}$ $\mathrm{ha}^{-1} \mathrm{yr}^{-1}$ ) employed in Alfaro's study. When comparing the results of $\mathrm{N}$ mineralization in grassland with other southern Chilean soils, it is evident that the net release during the current study is higher than the values reported for forest ecosystems and crop production systems (Rivas et al., 2009). This can be explained by the fact that the demand of mineralized $\mathrm{N}$ during the formation of the microbial biomass in grasslands could be higher than the requests of some evaluated forests and crops (Lobos et al., 2014).

The long-term aerobic incubation allowed the determination of soil $\mathrm{N}$ mineralization, nevertheless, it was a time consuming technique. The anaerobic incubation technique was a short time alternative that also allowed the estimation of the potential mineralized $\mathrm{N}$. The results of the laboratory incubation were higher than the mineralization rates obtained on other laboratory assays carried out employing southern Chilean volcanic soils (e.g. Alfaro et al., 2009b; Cartes et al, 2009). This may be because this experiment was carried out after three years of management with systematic $\mathrm{N}$ applications and plant uptakes, and because, in some of the other studies, higher acidic soils were used, considering that the $\mathrm{pH}$ is an important factor that influences the activity of the biomass responsible for the SOM decomposition. The high PRNMR determinate in the laboratory incubation experiment showed differences in the slurry treated soil, maybe due to the combined effect of the SOM and higher temperatures which enhanced the microorganism activity at a short-term time period (Chadwick et al., 2000). However, the results of the field experiment showed a marked, favorable response to the urea fertilizer application, which in turn could be the response to higher rates of gross $\mathrm{N}$ mineralization and lower rates of gross $\mathrm{N}$ immobilization which allows a larger $\mathrm{NH}_{4}^{+}-\mathrm{N}$ pool maintained in time, with higher 
net mineralization rates (Antil et al., 2001). Besides, soil $\mathrm{N}$ immobilization process could be overcome by the addition of the $\mathrm{N}$ in the fertilizers, regardless of the applied source (Cárdenas et al., 2013).

Results of the current study, and others mentioned above, suggest that $\mathrm{N}$ mineralization is an important factor that must be taken into consideration in controlling the amount of $\mathrm{N}$ loss from the soil surface through different pathways. The Andosols of Osorno Serie in southern Chile could retain some $\mathrm{N}$ amounts, remaining in the soil matrix until it becomes available to plants in the peaking demand periods. In this time there is greater $\mathrm{N}$ extraction, but at the same time there is an increasing microorganism's activity, which converts the organic $\mathrm{N}$ into inorganic $\mathrm{N}$ forms, becoming available for its utilization (Lobos et al., 2014; Cárdenas et al., 2013).

A part of the $\mathrm{NH}_{4}^{+}-\mathrm{N}$, the one close to the soil surface, may be the primary source for the activation of the $\mathrm{NH}_{3}$ volatilization processes, which, according to results reported by Salazar et al. (2014) and Martínez-Lagos et al. (2014) can be one of the principal pathways of $\mathrm{N}$ loss in local grassland systems, depending on the local climate and soil conditions.
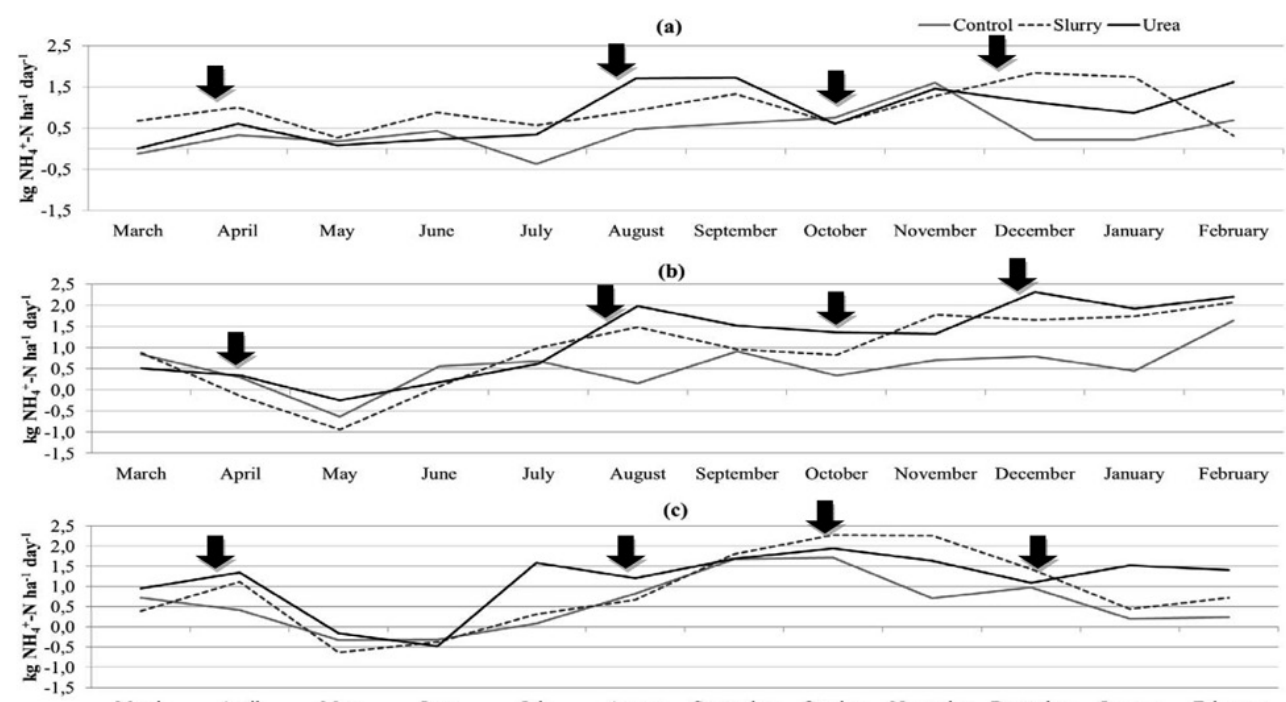

Figure 3. Seasonal pattern of daily $\mathrm{N}$ mineralization $\left(\mathrm{kg} \mathrm{NH}_{4}^{+}-\mathrm{N} \mathrm{ha}^{-1}\right.$ day $\left.^{-1}\right)$ during (a) March 2008 - February 2009; (b) March 2009 - February 2010 and (c) March 2010 - February 2011 at the Andosol soil. Arrows ( ) indicate fertilizer application date. 
Table 3. Results of $\mathrm{N}$ mineralization $( \pm$ SEM) per treatment and year.

\begin{tabular}{cccc}
\hline \multirow{2}{*}{ Treatment } & Study period & \multicolumn{2}{c}{ Nitrogen mineralization } \\
\cline { 2 - 4 } & March 2008 - February 2009 & $154.2 \pm 4.59$ & $0.4 \pm 0.30$ \\
\hline \multirow{3}{*}{ Control } & March 2009 - February 2010 & $206.4 \pm 3.36$ & $0.6 \pm 0.23$ \\
& March 2010 - February 2011 & $218.6 \pm 2.55$ & $0.6 \pm 0.21$ \\
\hline \multirow{3}{*}{ Slurry } & March 2008 - February 2009 & $342.6 \pm 6.42$ & $1.0 \pm 0.43$ \\
& March 2009 - February 2010 & $344.8 \pm 4.29$ & $0.9 \pm 0.29$ \\
& March 2010 - February 2011 & $320.3 \pm 7.02$ & $0.9 \pm 0.65$ \\
\hline \multirow{2}{*}{ Urea } & March 2008 - February 2009 & $314.6 \pm 6.36$ & $0.9 \pm 0.41$ \\
& March 2009 - February 2010 & $411.3 \pm 3.88$ & $1.2 \pm 0.26$ \\
& March 2010 - February 2011 & $420.9 \pm 5.00$ & $1.1 \pm 0.44$ \\
\hline
\end{tabular}

*Statistically significant differences between treatments in the column $(p<0.05)$

\section{Conclusions}

In urea and slurry fertilized soils, $\mathrm{N}$ mineralization ranged between $314-420$ and $320-344 \mathrm{~kg} \mathrm{NH}_{4}^{+}-\mathrm{N}$ $\mathrm{ha}^{-1} \mathrm{yr}^{-1}$, respectively; while in soil without $\mathrm{N}$ fertilization between $154-218 \mathrm{~kg} \mathrm{NH}_{4}^{+}-\mathrm{N} \mathrm{ha}^{-1} \mathrm{yr}^{-1}$ was mineralized $(p<0.05)$. Most of the $\mathrm{N}$ was mineralized in the spring and summer seasons $(p<0.05)$, with mineralization rates of up to 1.2 and $1.0 \mathrm{~kg} \mathrm{NH}_{4}^{+}-\mathrm{N}$ $\mathrm{ha}^{-1}$ day $^{-1}$ for urea and slurry treated soils, respectively. The average annual net mineralization of the studied years was 189 and $143 \mathrm{~kg} \mathrm{NH}_{4}^{+}-\mathrm{N} \mathrm{ha}^{-1}$ for urea and slurry, respectively. Laboratory results indicated that slurry treated soils had a higher potential residual $\mathrm{N}$ net mineralization than urea treated plots $(p<0.05)$. The results of the current study and others indicate that in some of the year's seasons, $\mathrm{N}$ mineralization could even be more important than the $\mathrm{N}$ fertilizer addition, regardless of whether its origin is organic or mineral. The results of the study suggest that $\mathrm{N}$ mineralization could be one of the major $\mathrm{N}$ inputs to the soil $\mathrm{N}$ budgets of southern Chilean grasslands. Thence $\mathrm{N}$ mineralization is an important factor in controlling the amount of $\mathrm{N}$ losses from the soil surface through different pathways such as $\mathrm{NH}_{3}$ volatilization.

\section{Acknowledgments}

This research was funded by the Scientific and Technological Research Council (FONDECYT 1080368 and 1130718). We also thank Evelyn Lazo for his technical field support during the third year of experimentation.

\section{References}

Aguilera, P., Briceño, G., Mora, M., Demanet, R., Palma, G. 2010. Effect of liquid cow manure on chemical and biological properties in an Andisol. R. C. Suelo Nutr. Veg 10(2): 158-169. 
Alfaro, M., Salazar, F., Ramírez, R., Rosas, A. 2013. Eficiencia real de uso de nitrógeno en praderas permanentes. Libro de Resúmenes, XXXVIII Congreso Anual SOCHIPA. 23-25 de Octubre, Frutillar, Chile. 125-126p.

Alfaro, M., Salazar, F., Oenema, O., Iraira, S., Teuber, N., Ramírez, L., Villarroel, D. 2009a. Nutrients balances in beef cattle production systems and their implications for the environment. R. C. Suelo Nutr. Veg. 9(1): 40-54.

Alfaro, M., Vistoso, E., Cárdenas, L., Salazar, F., Hatch, D. 2009b. Mineralización potencial de nitrógeno en suelos derivados de cenizas volcánicas. Libro de Resúmenes, XXXIV Congreso Anual SOCHIPA. 21-23 de Octubre, Pucón, Chile. 42-43p.

Antil, R., Lovell, R., Hatch, D., Jarvis, S. 2001. Mineralization of nitrogen in permanent pastures amended with fertilizer or dung. Biol. Fertil. Soils. 33, 132-138.

Cárdenas, L., Hatch, D., Scholefield, D., Jhurreea, D., Clark, I., Hirsch, P., Salazar, F., Rao-ravella, S., Alfaro, M. 2013. Potential mineralization and nitrification in volcanic grassland soils in Chile. $\mathrm{J}$. Soil Sc. Plant Nutr. 59(3):380-391.

Cartes, P., Jara, A., Demanet, R. Mora, M. 2009. Urease activity and nitrogen mineralization kinetics as affected by temperature and urea input rate in Southern Chilean Andisols. R. C. Suelo Nutr. Veg. 9(1): 69-82.

Chadwick, D., John, F., Pain, B., Chambers, B., Williams, J. 2000. Plant uptake of nitrogen from the organic nitrogen fraction of animal manures: a laboratory experiment. J. Agr. Sci. 134, 159-168.

CIREN. 2005. Descripciones de suelos, materiales y símbolos. Estudio agrológico X Región, Tomo II. Publicación $N^{\circ} 123$. Centro de Información de Recursos Naturales (CIREN), Santiago, Chile.
Córdova, C., Barrandeguy, M. and Navarrete, E. 2012. Soil quality of first rotation Eucalyptus stands growing on an Andisol using soil microbial indicators. J. Soil Sci. Plant Nutr. 12(3):575-579.

Hatch, D., Sprosen, M., Jarvis, S., Ledgard, S. 2002. Use of labeled nitrogen to measure gross and net rates of mineralization and microbial activity in permanent pastures following fertilizer applications at different time intervals. Rapid Commun Mass Spectrom. 16, 2172-2178.

Hatch, D., Lovell, R., Antil, R., Jarvis, S., Owen, P. 2000. Nitrogen mineralization and microbial activity in permanent pastures amended with nitrogen fertilizer or dung. Biol. Fertil. Soils. 30, 288-293.

Hatch, D., Jarvis, S., Parkinson, R. 1998. Concurrent measurements of net mineralization, nitrification, denitrification and leaching from field incubated soil cores. Biol. Fertil. Soils. 26, 323-330.

Hatch, D., Jarvis, S., Reynolds, S. 1991. An assessment of the contribution of net mineralization to $\mathrm{N}$ cycling in grass swards using a field incubation method. Plant Soil. 138, 23-32.

Hatch, D., Jarvis, S., Philipps, L. 1990. Field measurement of nitrogen mineralization using soil core incubation and acetylene inhibition of nitrification. Plant and Soil. 124, 97-107.

Huygens, D., Roobroeck, D., Cosyn, L., Salazar, F., Godoy, R., Boeckx, P. 2010. Microbial nitrogen dynamics in south central Chilean agricultural and forest ecosystems located on an Andisol. Nutr. Cycl. Agroecosyst. 1-13.

IUSS. 2007. World Reference Base for Soil Resources 2006; a framework for international classification, correlation and communication. Working Group WRB. World Soil Resources Reports No. 103. FAO, Rome, Italy. 
Jarvis, S., Hatch, D., Lovell, R. 2001. An improved soil core incubation method for the field measurement of denitrification and net mineralization using acetylene inhibition. Nutr. Cycl. Agroecosys. 59, 219-225.

Lober, R., Reeder, J. 1993. Modified waterlogged incubation method for assessing nitrogen mineralization in soils and soil aggregates. Soil Science Society of America Journal. 57, 400-403.

Lobos, I., Alfaro, M., Ramírez, L., Rosas, A., Martínez-Lagos, J. 2014. Optimization of nitrogen fertilization in pastures. Submitted to Chilean Journal of Agricultural Research.

Martínez-Lagos, J., Salazar, F., Alfaro, M., Rosas, M., Rampoldi, E., Macías, F. 2014. Factores edafoclimáticos que afectan las emisiones de amoniaco por aplicación de urea y purín de lechería en Andosoles. Chilean Journal of Agricultural and Animal Sciences. 30(1):15-28.

Matus, F., Lusk, C., Maire, C. 2008. Effects of Soil Texture, Carbon Input Rates, and Litter Quality on Free Organic Matter and Nitrogen Mineralization in Chilean Rain Forest and Agricultural Soils. Commun. Soil Sci. Plan. 39, 187-201.

Mora, M., Cartes, P., Núñez, P., Salazar, M., Demanet, R. 2007. Movement of $\mathrm{NO}_{3}^{-}-\mathrm{N}$ and $\mathrm{NH}_{4}^{+}-\mathrm{N}$ in an Andisol and its influence on ryegrass production in a short term study. J. Soil Sc. Nutr. 7(2): 46-64.

Núñez, P., Demanet, R., Misselbrook, T., Alfaro, M., Mora, M. 2010. Nitrogen losses under different cattle grazing frequencies and intensities in a volcanic soil of southern Chile. Ch. J. Agric. Res. 70(2): 237-250.

ODEPA. 2013a. Leche: producción, recepción, precios y comercio exterior. Oficina de Estudios y Políticas Agrarias (ODEPA). Available at: http:// www.odepa.cl/wp-content/uploads/2013/12/ informe_lacteo_1113.pdf. [accessed at 16.08.14].
ODEPA. 2013b. Informe con detalle regional y mensual (Pecuario). Oficina de Estudios y Políticas Agrarias (ODEPA). Available at: http:// www.odepa.cl/informe-con-detalle-regional-ymensual-pecuario. [accessed at 16.08.14].

Ortega, B., Mardonez, R. 2005. Variabilidad espacial de la mineralización de nitrógeno en un suelo volcánico de la provincia de Ñuble, VIII Región, Chile. Agr. Tec. 65(2): 221-231.

Pinochet, D., Mendoza, J., Galvis, A. 2000. Potencial de mineralización de nitrógeno de un Hapludand con distintos manejos agrícolas. Cienc. Investig. Agrar. 27(2): 97-106.

Rivas, Y., Oyarzún, C., Godoy, R., Valenzuela, E. 2009. Mineralización del nitrógeno, carbono y actividad enzimática del suelo en un bosque de Nothofagus obliqua (Mirb) Oerst y una plantación de Pinus radiata D. Don. del centro-sur de Chile. Rev. Chil. Hist. Nat. 82, 119-134.

Sadsawka, A., Carrasco, M., Grez, R., Mora, M., Flores, H., Neaman, A. 2006. Métodos de análisis recomendados para los suelos de Chile. Serie Actas INIA $\mathrm{N}^{\circ} 34.163$ p. Instituto de Investigaciones Agropecuarias (INIA), Santiago, Chile.

Salazar, F., Martínez-Lagos, J., Alfaro, M., Misselbrook, T. 2014. Ammonia emission from a permanent grassland on volcanic soil after the treatment with dairy slurry and urea. Atmos. Environ. 95, 591-597.

Salazar, F., Martínez-Lagos, J., Alfaro, M., Misselbrook, T. 2012. Low nitrogen leaching losses following a high rate of dairy slurry and urea application to pasture on a volcanic soil in Southern Chile. Agr. Ecosyst. Environ. 160, 23-28.

Salazar, F., Alfaro, M., Ledgard, S., Iraira, S., Teuber, N., Ramírez, L. 2011. Effect of the stocking rate and land slope on nitrogen losses to water on a grazed pasture of southern Chile. J. Soil Sci. Plant Nutr. 11(2):97-108. 
Schimel, J., Bennet, J. 2004. Nitrogen mineralization: Challenges of a changing paradigm. Ecology. 85(3): 591-602.

Soil Survey Staff. 2010. Keys to Soil Taxonomy. 11th. ed. USDA. Natural Resources Conservation Service, Washington, DC, USA.

Tosso, J. 1985. Suelos Volcánicos de Chile. Ministerio de Agricultura, Instituto de Investigaciones Agropecuarias, ODEPA, Santiago, Chile.

Videla, X., Parada, A., Nario, A., Pino, I., Hood, R. 2005. Efecto del contenido de agua en la mineralización bruta e inmovilización de nitrógeno. Agr. Tec. 65(1):74-78.
Vistoso, E., Alfaro, M., Saggar, S., Salazar, F. 2012. Effect of nitrogen inhibitors on nitrous oxide emissions and pasture growth following an autumn application in a volcanic soil. Chil. J. Agr. Res. 72(1):133-139.

Vistoso, E., Bolan, N., Theng, B., Mora, M. 2009. Kinetics of molybdate and phosphate sorption by some Chilean Andisols. J. Soil Sc. Plant Nutr. 9(1):55-68. 